\title{
ARTIKELEN
}

\section{Een stok in het duister: boetes voor niet-tijdige inburgering en rechtszekerheid}

\author{
Jeremy Bierbach
}

\section{Inleiding}

Als beoefenaar van het Nederlandse vreemdelingenrecht heb ik veel te maken met het Nederlandse inburgeringsbeleid. Het overgrote deel van mijn cliënten betreft vreemdelingen die in het bezit zijn van een verblijfsvergunning regulier of asiel, die dus als zodanig onderworpen zijn aan de op 1 januari 2007 in werking getreden Wet inburgering (Wi). ${ }^{1}$ Deze wet, ontworpen door de toenmalige minister voor Vreemdelingenzaken en Integratie Rita Verdonk (VVD), diende ter vervanging van de op 30 september 1998 in werking getreden Wet inburgering nieuwkomers (Win). ${ }^{2}$ Zowel de Win als de Wi voorzien in de mogelijkheid voor uitvoerende bestuursorganen bestuurlijke boetes op te leggen aan inburgeringsplichtige derdelanders die niet voldoen aan bepaalde verplichtingen. Aangezien een boete in wezen een strafmaatrege ${ }^{3}$ is, die in dit geval enkel kan worden opgelegd aan een immigrant, valt deze dimensie van het inburgeringsbeleid bij uitstek te beschouwen als onderdeel van het fenomeen crimmigratie, waarbij het strafrecht en het immigratierecht met elkaar vervlochten raken. ${ }^{4}$

Voor cliënten probeer ik inburgering zo simpel mogelijk samen te vatten als volgt. Het beleid bestaat grosso modo uit twee prikkels om kennis te verwerven van de Nederlandse taal en samenleving: enerzijds de 'wortel' (door aan te tonen dat je ingeburgerd bent, kom je in aanmerking voor sterkere, minder voorwaardelijke verblijfsrechten of voor de Nederlandse nationaliteit $)^{5}$ en anderzijds de 'stok' (als je niet op tijd aantoont dat je ingeburgerd bent, krijg je een boete). In beide gevallen voldoe je in het algemeen aan de voorwaarde, dan wel aan de verplichting, door het inburgeringsexamen te halen. Deze metafoor geeft de kennelijke verwevenheid weer tussen de Wi (de wettelijke basis voor de 'stok', alsmede voor de inhoud van het inburgeringsexamen), de Vreemdelingenwet 2000 (Vw 2000; waarin inburgeringsvoorwaarden, onder verwijzing naar de $\mathrm{Wi}$, worden gesteld

1 Wet van 30 november 2006, houdende regels inzake inburgering in de Nederlandse samenleving, Stb. 2006, p. 625.

2 Wet van 9 april 1998, houdende regels met betrekking tot de inburgering van nieuwkomers in de Nederlandse samenleving, Stb. 1998, p. 261.

3 Dus ook een criminal charge in de zin van art. 6 Europees Verdrag voor de Rechten van de Mens (EVRM).

4 Van der Woude, Van der Leun \& Nijland, 'Crimmigration in the Netherlands', p. 2.; Van der Woude, 'Crimmigratie'.

5 Wellicht is dit de meer voor de hand liggende betekenis van 'inburgering', namelijk in de zin van 'staatsburger worden' (vgl. het Duitse woord 'Einbürgerung', dat 'naturalisatie' betekent). 
voor de 'wortel' van een onvoorwaardelijk verblijfsrecht) en de Rijkswet op het Nederlanderschap (RWN; waarin de voorwaarden, via het Besluit naturalisatietoets en eveneens onder verwijzing naar de $\mathrm{Wi}$, worden gesteld voor naturalisatie tot Nederlander).

Ik zal eerst een korte samenvatting geven van de geschiedenis van de ontwikkeling van de Wet inburgering. Vervolgens zal ik het boetestelsel van de Wet inburgering langs de meetlat van de rechtszekerheid leggen. Weet de inburgeringsplichtige daadwerkelijk waar zij of hij aan toe is met deze boetebepalingen, op een vergelijkbare manier met de bepalingen van het strafrecht waarmee iedere burger geacht kan worden bekend te zijn? Rechtszekerheid is wenselijk om meerdere redenen, allereerst vanuit het instrumentele streven 'de norm, of althans de sanctie, een rol te laten spelen in de praktische overwegingen van de geadresseerden en het spreekt vanzelf dat men slechts zal slagen als de geadresseerde op de hoogte is van het recht en het eigen doen en laten daarop kan afstemmen.' Rechtsonzekerheid, daarentegen, geeft blijk van een moreel gebrek (vanuit het ideaal van menselijke vrijheid en autonomie) in degene die niet of moeilijk kenbare normen stelt: hij 'ontneemt zo iemand de mogelijkheid om zelf te kiezen en behandelt hem of haar niet als persoon'. ${ }^{7}$

Ik zal het inburgeringsstelsel zoveel mogelijk 'deontologisch' proberen te ontleden, in termen van de verplichtingen die verschillende inburgeringsplichtigen geacht worden te hebben en waarom. In mijn analyse zal het niet helemaal mogelijk blijken om de 'stok' van de 'wortel' te ontvlechten: op welke wijzen kan het ontzeggen van de 'wortel' ook een straf zijn? Bovendien zal een derde dimensie van het inburgeringsbeleid een rol spelen, namelijk de inhoudelijke bevordering (niet enkel met prikkels) van het verwerven van de voorgeschreven kennis. Op welke wijzen wordt bevordering, in de vorm van financiering van cursussen, gekoppeld aan het bestaan van een inburgeringsplicht stricto sensu? Op welke wijze is het gebleken gebruik van voorgeschreven cursussen van invloed op de mogelijkheid beboet te worden? En hoe wordt het achteraf intrekken van bevordering gebruikt als een prikkel op zich, een andere soort (en vaak veel zwaardere) stok dan een boete?

Vervolgens zal ik ingaan op de Unierechtelijke aspecten aan de hand van het arrest van het Hof van Justitie in de zaak P. en S., ${ }^{8}$ het eerste arrest waarin de verenigbaarheid van het Nederlandse inburgeringsstelsel met het Unierecht aan de orde was, en het enige tot nu toe waarin boetes voor niet-tijdige inburgering aan de orde waren. Omdat ik ook de gemachtigde was van mevrouw P. en mevrouw S., de appellanten in die zaak, kan ik de zaak verder toelichten aan de hand van hoe de appellanten de Wi als mensen (en geen juristen) beleefd hebben.

6 Brouwer, 'Onvermijdelijke rechtsonzekerheid?’, p. 184.

7 Brouwer, p. 186.

8 HvJ EU 4 juni 2015, P, S tegen Commissie Sociale Zekerheid Breda, College van Burgemeester en Wethouders van de gemeente Amstelveen, C-579/13, ECLI:EU:C:2015:369, JV 2015/208 m.nt. dr. K.M. de Vries. 


\section{De voorgeschiedenis van de Wet inburgering}

Dat de wortel en de stok als twee kanten van hetzelfde instrument worden beschouwd, is geenszins vanzelfsprekend. Die sterke verwevenheid bestaat pas (met opzet) sinds de inwerkingtreding van de Wi. De Win, die grotendeels voorzag in het bevorderen van een door gemeenten uit te voeren inburgeringsprogramma voor 'nieuwkomers', dat afgesloten werd met een toets, trad in werking ongeveer gelijktijdig met een koerswijziging in het politieke discours rond naturalisatie. Voorheen werd het Nederlanderschap zelf beschouwd als een middel om de integratie van migranten te bevorderen. Maar na de invoering van de Win gingen er stemmen op om integratievoorwaarden in te voeren voor 'oudkomers' die Nederlander wilden worden, als uitdrukking van de idee (in de woorden van CDAKamerlid Verhagen in een debat op 16 februari 2000) ${ }^{9}$ dat het Nederlanderschap 'de bekroning [is] van de integratie in de Nederlandse samenleving, de eindfase daarvan' moest zijn.

$\mathrm{Na}$ de opkomst van en politieke moord op Pim Fortuyn, nam zijn LPF deel aan een kortstondig kabinet (Balkenende I) waarin een nieuwe ministerspost 'Vreemdelingenzaken en Integratie' gecreëerd werd. De ministerspost bleef bestaan na de val van Balkenende I, inmiddels bekleed in Balkenende II door Rita Verdonk, en nu was het integratiebeleid (los van naturalisatievereisten) aan de beurt: het samenvoegen van integratie (voorheen een taak van de minister van Binnenlandse Zaken) met immigratie was tekenend voor het 'justitialiseren' van integratieverplichtingen. ${ }^{10}$ Op 15 maart 2006 trad eerst Verdonks Wet inburgering buitenland ${ }^{11}$ in werking, een belangrijke toevoeging aan de Vw 2000 waarbij een 'basisexamen inburgering' op een Nederlandse consulaire vertegenwoordiging een vereiste werd voor aanvragen voor gezinshereniging waarvoor een mvv vereist ${ }^{12}$ is.

In Verdonks voorstel voor de nieuwe Wet inburgering moesten bestuurlijke boetes (voor het niet verschijnen op profielgesprekken, het niet afmaken van een inburgeringscursus, enzovoort) die onder de Win slechts zelden werden opgelegd ${ }^{13}$ wijken voor een veel dwingender boetestelsel. ${ }^{14}$ De nieuwe inburgeringsplicht, in tegenstelling tot de oude deelnameverplichting, 'is een resultaatsverplichting en houdt in dat aan de verplichting pas is voldaan als inburgeringsplichtigen slagen voor het inburgeringsexamen. ${ }^{15}$ De overheid zou 'heldere en kenbare

9 TK 1999-2000, 50-3634.

10 Van Oers, Deserving Citizenship, 42-43. Groenendijk, 'Legal Concepts of Integration in EU Migration Law', p. 113.

11 Wet van 22 december 2005 tot wijziging van de Vreemdelingenwet 2000 in verband met het stellen van een inburgeringsvereiste bij het toelaten van bepaalde categorieën vreemdelingen, Stb. 2006, 28.

12 Tekenend hiervoor is de lijst van nationaliteiten die al vrijgesteld zijn van het mvv-vereiste, en dus ook bij voorbaat van het basisexamen: de Verenigde Staten, Canada, Australië, Nieuw-Zeeland, Japan, Zuid-Korea en Vaticaanstad.

13 Odé en Brink, 'Verscheidenheid in integratie. Evaluatie van de Wet inburgering nieuwkomers', p. 156.

14 van Oers, Deserving Citizenship, 46.

15 Nota 'Herziening van het inburgeringsstelsel', TK 2003-2004, 29543 nr. 2. 
vereisten [...] formuleren waaraan inburgeringsplichtigen moeten en redelijkerwijs ook kunnen voldoen.' 16

\section{Wie moet wat van welk bestuursorgaan op grond van welke versie en wanneer?}

Allereerst dient zich de vraag aan wie: in eerste instantie kunnen alleen derdelanders die houder zijn van een verblijfsvergunning regulier of asiel voor bepaalde tijd inburgeringsplichtig zijn op grond van artikel 3 eerste lid van de huidige versie van de Wi. In de tot 1 januari 2013 geldende versie waren ook houders van een verblijfsvergunning regulier of asiel voor onbepaalde tijd inburgeringsplichtig, een situatie die aan de orde zal zijn in de bespreking van $P$. en $S$.

Het valt buiten het bestek van dit artikel om de vele wijzigingen in de Wi in de loop der jaren uitvoerig te inventariseren, hoewel een van de grootste verschuivingen de wijziging (m.i.v. 1-1-2013) betrof van het bestuursorgaan dat verantwoordelijk is voor het opleggen van boetes, namelijk van het college van B\&W van de betreffende woongemeente naar de Dienst Uitvoering Onderwijs (onder de verantwoordelijkheid van een reeks ministers, thans de minister voor Sociale Zaken en Werkgelegenheid). Het verdient opmerking dat de boetebepalingen van iedere respectievelijke versie, inclusief de aanwijzing van het verantwoordelijke bestuursorgaan, alleen kunnen gelden voor personen die inburgeringsplichtig worden na de inwerkingtreding van die versie, aangezien de inburgeringsplicht niet met terugwerkende kracht kan worden gevestigd (art. 3 vierde lid Wi). Als wij moeite doen om de veranderende verplichtingen van de wet in termen van rechtszekerheid op te vatten, moeten wij het moment dat een nieuwkomer rechtmatig verblijf verwerft, aanmerken als het moment dat de vreemdeling een 'contract' wordt geacht aan te gaan met de Nederlandse staat, met de op dat moment geldende tekst.

De wie wordt nader gespecificeerd (in art. 3 eerste lid onder $a \mathrm{Wi}$ ) als de vreemdeling die 'anders dan voor een tijdelijk doel in Nederland verblijft' of (onder $b$ ) 'geestelijke bedienaar is'. De definitie van 'tijdelijk' wordt ondergebracht in het Besluit inburgering (art. 2.1 eerste lid), waar wij grofweg alle verblijfsdoelen vinden die met studie, arbeid, uitwisseling en medische behandeling te maken hebben. (Verder wordt bepaald dat degene die als verblijfdoel 'verblijf bij familieof gezinslid' heeft bij een persoon die verblijft voor een 'tijdelijk' doel, eveneens 'tijdelijk' is, dus ter uitsluiting van gezinsleden van met name Nederlanders en derdelanders die houder zijn van een verblijfsvergunning voor onbepaalde tijd.)

Met deze idiosyncratische definitie van 'tijdelijk' verblijf sluit de Wi al niet meer aan op de systematiek van de Vw 2000, die deze term gebruikt om de verblijfsdoelen aan te wijzen in verband waarmee de houder niet gerechtigd is om een aan- 
vraag in te dienen voor een verblijfsvergunning regulier voor onbepaalde tijd (art. 21 eerste lid onder $f \mathrm{Vw}$ 2000) of een verblijfsvergunning als langdurig ingezetene (art. 45b eerste lid onder a Vw 2000). De RWN, met haar definitie ${ }^{17}$ van wie een aanvraag voor naturalisatie mag indienen omdat er geen 'bedenkingen tegen verblijf voor onbepaalde tijd' zijn (art. 8 eerste lid onder b), sluit grotendeels aan bij het onderscheid van de Vw 2000.

De definitie van 'tijdelijkheid' in vreemdelingenrechtelijke zin treft men aan in 3.5 tweede lid Vb 2000: hier vindt men ook bijvoorbeeld studie, uitwisseling en medische behandeling, alsmede arbeidsgerelateerde verblijfsdoelen van kennelijk beperkte duur zoals lerend werken, seizoenarbeid en verblijf in het kader van een zoekjaar (na het afstuderen aan een Nederlandse hogeronderwijsinstelling). Maar arbeidsgerelateerde verblijfsdoelen die 'tijdelijk' zijn in de zin van de Wi, zoals arbeid in loondienst, arbeid als zelfstandige en arbeid als kennismigrant, zijn dan weer 'niet-tijdelijk' in de zin van de Vw 2000. Hier wordt het verband tussen de wortel en de stok dan weer losgelaten: de 'expat' wil men kennelijk niet met de stok bedreigen, maar men vindt dat die wel verleid mag worden met de 'wortel' om een aanvraag voor een onvoorwaardelijke verblijfsstatus in te dienen.

Er zijn andersom ook voorbeelden denkbaar van vreemdelingen die met de 'stok' bedreigd kunnen worden zonder in aanmerking te komen voor een 'wortel', hoewel de afwijking hier ontstaat eerder door situationele veranderingen dan door categoriale uitsluiting. Bijvoorbeeld, een houder van een verblijfsvergunning asiel voor bepaalde tijd en diens nareizend gezinslid hebben geen 'tijdelijk' verblijf in de zin van de Wi en worden dus verplicht het inburgeringsexamen binnen drie jaar te halen, maar komen pas na vijf jaar in aanmerking voor een verblijfsvergunning asiel voor onbepaalde tijd of een verblijfsvergunning als langdurig ingezetene. Als de grond voor verlening van de verblijfsvergunning vervalt door een verandering in het thuisland tussen het drie- en het vijf-jaar-punt en de verblijfsvergunning wordt ingetrokken, wordt de wortel ook aan die vreemdeling ontzegd. Een soortgelijke situatie doet zich voor bij houders van reguliere verblijfsvergunningen in verband met gezinshereniging bij Nederlanders en niet-tijdelijke (in de zin van de Wi) vreemdelingen, die na drie jaar een boete kunnen krijgen maar pas na vijf jaar ${ }^{18}$ verblijf als gezinslid in aanmerking komen voor een onafhankelijke verblijfsvergunning voor onbepaalde tijd of bepaalde tijd met de beperking 'humanitair niet-tijdelijk' (ofwel 'voortgezet verblijf').

Uit deze voorbeelden blijkt dat de term 'tijdelijk' in zowel de Wi als de Vw 2000 een pure abstractie is, die weinig aansluiting heeft op de leefwereld ${ }^{19}$ van migranten.

In alle versies van de Wi tot nu toe bestaat de voornaamste 'stok' uit een bestuurlijke boete (die thans maximaal $€ 1.250$ bedraagt) die kan worden opgelegd een

17 Handleiding RWN, Toelichting op 1-1-g, par. 3.

18 Met ingang van 1 oktober 2012; daarvóór bedroeg deze termijn drie jaar. 'Besluit van 27 maart 2012 tot wijziging van het Vreemdelingenbesluit 2000, het Besluit modern migratiebeleid en het Besluit inburgering (aanscherping eisen gezinsmigratie)', Stb. 2012, p. 148.

19 Met deze term verwijs ik bewust, en ook in het algemeen, naar 'Inburgering: systeemwereld versus leefwereld; Evaluatie Wet inburgering 2013'. 
aantal jaren (tot 1-1-2013: 3,5 jaar; sindsdien drie jaar, waarvan sinds 1-10-2017 het eerste jaar als termijn geldt om de participatieverklaring te ondertekenen) nadat iemand inburgeringsplichtig wordt, indien de inburgeringsplichtige niet slaagt voor het inburgeringsexamen (of de participatieverklaring niet ondertekent) binnen de geldende termijn. De termijn kan worden verlengd 'indien de inburgeringsplichtige aannemelijk maakt dat hem geen verwijt treft' voor het niet voldoen aan de verplichting.

Met het gebruik van de term 'verwijt' in de betreffende bepalingen van de Wi ligt een vergelijking met het strafrecht voor de hand, waarin verwijtbaarheid een essentieel element is van het schuldbegrip (in de enge zin), dat ook zelfstandig bewezen moet worden in het strafproces. Maar het lijkt veeleer dat in de Wi niet zozeer bedoeld wordt door de wetgever dat het uitvoerende bestuursorgaan 'verwijtbaarheid' als zelfstandig element beoordeelt alvorens de termijn al dan niet te verlengen. Met andere woorden, de al dan niet 'verwijtbaarheid' ligt eerder per definitie besloten in de toepassing van geobjectiveerde voorwaarden die worden gesteld in de Regeling Inburgering (art. 2.4c, vanaf 23-5-2013) voor wanneer de termijn wordt verlengd. In ieder geval, als de inburgeringsplichtige 300 uur heeft deelgenomen aan een inburgeringscursus met een 'Blik op Werk'-keurmerk en tweemaal gezakt is voor onderdelen van het inburgeringsexamen, wordt de termijn verlengd (op aanvraag van de inburgeringsplichtige) omdat de overschrijding van de termijn kennelijk niet aan de inburgeringsplichtige te verwijten valt.

Die regel leidde aanvankelijk tot situaties waarin inburgeringsplichtigen, die kennelijk hoger wilden presteren door niet het inburgeringsexamen (Nederlands op A2-niveau) te halen maar het Staatsexamen Nederlands als Tweede Taal ('NT2', Programma I: B1, of Programma II: B2/C1), en daarin vertraging opliepen, effectief 'verweten' werd dat zij niet op het laagste niveau wilden inburgeren. De (thans nog) verantwoordelijke minister (van Sociale Zaken en Werkgelegenheid), Wouter Koolmees (D66), maakte een einde aan deze apert onredelijke situatie op 13 maart $2018^{20}$ door aan de regel toe te voegen dat verlenging ook zou worden verleend in situaties waarin de inburgeringsplichtige 300 uur heeft deelgenomen aan een cursus NT2 en twee keer gezakt is voor onderdelen van het Staatsexamen NT2.

De door de minister aangevoerde motivering hiervoor - '[h] oe hoger het inburgeringsniveau van de inburgeringsplichtige, des te beter diens kansen op de arbeidsmarkt en de mogelijkheden om te participeren in de Nederlandse samenleving' -

20 'Regeling van de Minister van Sociale Zaken en Werkgelegenheid van 13 maart 2018, nr. 2018-0000037011, tot wijziging van de Regeling inburgering in verband met het aanpassen van de regels omtrent ontheffing en verlenging', Stcrt. 2018, 15700. 
is niet zomaar een ingeving uit doelmatigheidsoverwegingen. ${ }^{21}$ Het is veel waarschijnlijker dat de inspiratie voor deze wijziging een uitspraak van de Rechtbank Noord-Nederland ${ }^{22}$ was, waarin deze het Staatsexamen NT2 gelijkstelde aan het inburgeringsexamen en de boete voor een op grond van de oude regel gedupeerde inburgeringsplichtige tot nihil reduceerde, onder toepassing van artikel 8:72a Algemene wet bestuursrecht.

Het uitvoerende bestuursorgaan is wél verplicht, maar dan niet op grond van de Wi zelf, om de verwijtbaarheid zelf te toetsen, op grond van artikel 5:4123 Awb. Onbekend is of, en zo ja, hoe vaak, DUO deze toetsing (die weleens verricht wordt door de bestuursrechter $)^{24}$ zelf verricht, maar de minister heeft in ieder geval inmiddels voorheen niet-openbaar beleid ${ }^{25}$ gepubliceerd met regels die gebruikt worden om de boete al dan niet te matigen, als uitwerking van artikel 5:46 tweede $\operatorname{lid}^{26}$

Tot slot, om deze selectie van kernaspecten van de 'stok' van de Wi af te ronden, moet er worden opgemerkt dat een van de grootste nadelen die een inburgeringsplichtige kan ervaren formeel gezien niet eens als een sanctie wordt beschouwd. De meeste inburgeringsplichtigen komen in aanmerking voor een lening om de inburgeringscursussen te betalen (waarbij het sinds 1-1-2013, overigens, de eigen

21 Opmerkelijk is dat al eerder, door Koolmees' voorganger Lodewijk Asscher, besloten is om m.i.v. 1-1-2015 niet langer vrijstelling te verlenen van het hele inburgeringsexamen voor degenen die het Staatsexamen haalden, maar ze alsnog te verplichten de onderdelen van het inburgeringsexamen 'Kennis van de Nederlandse Samenleving' en 'Oriëntatie op de Nederlandse Arbeidsmarkt' te halen om in aanmerking te komen voor een verblijfsvergunning voor onbepaalde tijd. Hiermee verdween juist een prikkel (verminderde examendruk) om het Staatsexamen te behalen. 'Besluit van 16 oktober 2014 tot wijziging van het Besluit inburgering en het Vreemdelingenbesluit 2000 in verband met de toevoeging van een praktijkexamen ten behoeve van de oriëntatie op de Nederlandse arbeidsmarkt aan het onderdeel kennis van de Nederlandse samenleving en enkele andere wijzigingen', Stb. 2014, p. 404.

2224 augustus 2017, ECLI:NL:RBNNE:2017:3316, JV 2017/256 m.nt. mr. dr. K.M. de Vries

23 'Het bestuursorgaan legt geen bestuurlijke boete op voor zover de overtreding niet aan de overtreder kan worden verweten.'

24 Bijv. Rb. Amsterdam, 21 juli 2017, ECLI:NL:RBAMS:2017:5176, die de opgelegde boete matigt onder toepassing van art. 5:46 eerste lid Awb. Vgl. ABRvS, 13 juni 2018, ECLI:NL:RVS: 2018:1961, die de boete en terugbetalingsplicht vernietigt omdat de termijn, zo stelt de Afdeling, had moeten worden verlengd, niet zozeer op grond van niet-verwijtbaarheid. Maar zie ook de zeer recente uitspraak van de ABRvS, 16 oktober 2019, ECLI:NL:RVS:2019:3474, waarin overwogen is dat de rechtbank terecht bepaalt dat de termijn had moeten worden verlengd op grond van niet-verwijtbaarheid.

25 'Beleidsregel van de Minister van Sociale Zaken en Werkgelegenheid van 13 maart 2018, 2018-0000041739, over de vaststelling van de boete bij verwijtbaar overschrijden van de inburgeringstermijn (Beleidsregel boetevaststelling inburgering)', Stcrt. 2018, 15704. Blijkens een recente uitspraak van de $A B R v S$ schijnt de minister nog steeds ongepubliceerd beleid te hebben voor matiging van boetes in verband met hoeveel onderdelen van het inburgeringsexamen gehaald zijn, zie de uitspraak van 14 april 2019, ECLI:NL:RVS:2019:1239.

26 'Tenzij de hoogte van de bestuurlijke boete bij wettelijk voorschrift is vastgesteld, stemt het bestuursorgaan de bestuurlijke boete af op de ernst van de overtreding en de mate waarin deze aan de overtreder kan worden verweten. Het bestuursorgaan houdt daarbij zo nodig rekening met de omstandigheden waaronder de overtreding is gepleegd.' 
verantwoordelijkheid is van de inburgeringsplichtige om een taalaanbieder te zoeken). ${ }^{27}$ Dit betreft de inhoudelijke bevordering van het inburgeringsproces waarin de Wi voorziet (die ook inhoudelijk wat minder is geworden sinds het aanbod van cursussen aan de markt is overgelaten). Maar speciaal voor asielmigranten en hun gezinsleden biedt de Wi een extra prikkel: ${ }^{28}$ als zij op tijd voldoen aan hun verplichtingen binnen de daarvoor vastgestelde termijn, wordt de lening geheel kwijtgescholden.

Deze prikkel, hoewel zonder twijfel goed bedoeld als een verlengstuk van de bevordering, wordt in wezen een extra sanctie voor deze, juist meest kwetsbare inburgeringsplichtigen die 'verwijtbaar' laat inburgeren. Zij worden opgezadeld met een forse schuld (het is bekend dat asielmigranten al fors meer lenen dan gezinsmigranten $)^{29}$ die zij anders niet zouden hebben gehad. Zelfs als een boete voor niet-tijdige inburgering tot het minimum ${ }^{30}$ wordt verminderd in verband met verminderde verwijtbaarheid, wordt de lening ${ }^{31}$ alsnog niet kwijtgescholden. Dus alleen inburgeringsplichtigen die geen enkel 'verwijt' treft voor het te laat inburgeren, in de definitie daarvan die in de Wi wordt gesteld, ten aanzien van wie dus te termijn verlengd is, komen onderuit aan deze terugbetalingsplicht. ${ }^{32}$

Om samen te vatten: om enige zekerheid te hebben of zij of hij gevaar loopt een boete te krijgen voor niet-tijdige inburgering, moet een inburgeringsplichtige weten, onder meer:

- $\quad$ welke versie van de wet gold op het moment dat hij of zij inburgeringsplichtig werd;

- wat voor soort verblijfsstatus hij of zij heeft; is die status 'tijdelijk' of 'niettijdelijk' in de zin van de Wi?

- of er al dan niet uitzonderingen van toepassing zijn en waarom: de ene heeft een verblijfsvergunning voor gezinshereniging met een Nederlander en vraagt zich af waarom hij inburgeringsplichtig is, terwijl de buurvrouw die eveneens gehuwd is met een Nederlander, maar die de 'Europa-route' volgde en dus als gemeenschapsonderdaan te kwalificeren valt, niet inburgeringsplichtig is;

- of hij lessen volgt bij een taalaanbieder met een 'Blik op Werk'-keurmerk, en zo ja, of hij voldoende uren les heeft gehad en een voldoende aantal keren is gezakt voor het inburgeringsexamen om een verlenging van de termijn te krijgen?

27 Zie, in het algemeen, 'Inburgering: systeemwereld versus leefwereld; Evaluatie Wet inburgering 2013', p. 47.

28 Art. 4.13 derde lid onder $a$ Besluit inburgering.

29 'Inburgering: systeemwereld versus leefwereld; Evaluatie Wet inburgering 2013', p. 58.

$30 € 250$ o.g.v. de Beleidsregel boetevaststelling inburgering.

31 Meestal in de orde van $€ 10.000$ of meer.

32 In een uitspraak d.d. 30 augustus 2019 heeft de Rechtbank Noord-Holland, zp Alkmaar (AWB 18/5609, nog niet gepubliceerd) ten aanzien van een cliënte van mij bepaald op grond van onder meer art. 5:41 Awb dat haar helemaal niet verweten kon worden dat het eindgesprek voor een onderdeel van het inburgeringsexamen (ONA) niet voor het verlopen van de termijn werd gehouden, zeker omdat het deels aan haar taalschool te wijten was dat het ONA-portfolio niet op tijd is opgestuurd naar DUO. (De minister is inmiddels in hoger beroep gegaan tegen deze uitspraak.) 
Bij wijze van vergelijking met algemeen bekende normen van het strafrecht of het wegenverkeersrecht, die consistent voor eenieder, te allen tijde gelden, laten de boetebepalingen van de $\mathrm{Wi}$ al enorm te wensen over in termen van rechtszekerheid. Termen zoals 'verwijt' hebben geen alledaagse betekenis, maar blijken primair te verwijzen naar abstracte toetsingsvoorwaarden.

Voorts is het inburgeringsbeleid in zijn geheel, met het (niet altijd consistente) verband tussen de 'wortel', de 'stok' en de beschikbare bevordering van inburgering uiterst verwarrend en moeilijk te ontleden in de basisoperatoren van de deontologie (ofwel de verplichtingenleer): ${ }^{33}$ toestemming (mag); gebod (moet); verbod (mag/moet niet); of ontheffing/vrijstelling (hoeft niet).

\section{Een omgekeerde wereld is mogelijk: inburgering en het Unierecht}

Zowel de Nieuw-Zeelandse mevrouw S. als de Amerikaanse mevrouw P. voelde zich gekwetst in haar rechtszekerheid. Ieder van deze twee derdelanders had minimaal vijf jaar ononderbroken rechtmatig verblijf in Nederland gehad met een verblijfsvergunning regulier voor bepaalde tijd $^{34}$ en ieder had in 2007, respectievelijk 2008, succesvol een verblijfsvergunning als 'langdurig ingezetene' aangevraagd, op basis van de toen recentelijk in werking getreden ${ }^{35}$ Richtlijn $2003 / 109$. Dit wetgevingsinstrument was een van de eerste dat aangenomen is door de Uniewetgever op de grondslag van een toen nog relatief nieuwe Unierechtelijke competentie die met het Verdrag van Amsterdam was ingevoerd (thans art. 79 Verdrag betreffende de Werking van de Europese Unie), namelijk de mogelijkheid de voorwaarden voor immigratie voor derdelanders te regelen in het Unierecht. De langdurig ingezetenen-Richtlijn beoogde de voorwaarden te harmoniseren waaronder derdelanders in een lidstaat van de $\mathrm{EU}^{36}$ in aanmerking konden komen voor een onvoorwaardelijk verblijfsrecht en gelijke behandeling met onderdanen van een gastlidstaat.

Artikel 5 tweede lid van de Richtlijn bepaalt dat de 'lidstaten mogen eisen dat onderdanen van derde landen voldoen aan integratievoorwaarden overeenkomstig het nationaal recht.' Maar op de respectievelijke momenten waarop P. en S. hun verblijfsvergunningen als langdurig ingezetene hadden aangevraagd, had de Nederlandse wetgever nog geen gebruikgemaakt van de optie om deze Richtlijnbepaling om te zetten in nationale wetgeving en integratievoorwaarden te stellen voor verlening van de status. Weliswaar was een kan-bepaling om het inburgeringsexamen als voorwaarde te stellen al met ingang van 1 januari 2007 ingevoerd in de Vw 2000 (art. 21 eerste lid onder k [toen]), maar tegelijkertijd werd er een

33 Brouwer, 'Basic concepts of European private law', 275-76.

34 S., een bankier, als arbeidsmigrant; P. als gezinsmigrant op grond van haar geregistreerd partnerschap met een Nederlandse vrouw.

35 M.i.v. 31 januari 2004, in Nederland aanvankelijk met rechtstreekse werking op grond van de niet-tijdige omzetting van de Richtlijn in nationale wetgeving.

36 Het Verenigd Koninkrijk, Ierland en Denemarken hebben een prominente opt-out bedongen van het hele hoofdstuk van het Verdrag waar immigratie onder valt, de 'ruimte van vrijheid, veiligheid en recht', dus ook van deze Richtlijn. 
overgangsbepaling ingevoerd dat de voorwaarde niet zou gelden voor aanvragers die hun aanvraag indienden vóór 21 september 2008 (later verlengd tot 1 januari 2010) en op dat moment vijf jaar houders waren van een verblijfsvergunning.

Beide vrouwen waren vanaf de verlening van deze verblijfsvergunningen (P. daarvóór al, S. voor het eerst) inburgeringsplichtig op grond van de $\mathrm{Wi}$, zijnde houders van een 'verblijfsvergunning regulier voor onbepaalde tijd', ${ }^{37}$ dus een verblijfsvergunning voor een niet-tijdelijk doel. Eind 2009 ontving P. een kennisgeving van $\mathrm{B} \& W$ van haar woongemeente Breda, en begin 2010 ontving S. een kennisgeving van haar woongemeente Amstelveen, waarin de termijn om het inburgeringsexamen te halen voor ieder van hen, als 'oudkomers', werd bepaald: 5 jaar vanaf 30 juni 2008 voor P. en 3,5 jaar vanaf 24 februari 2010 voor S. Geen van beide brieven maakte melding van een boete na verloop van de termijn, of anders wat het concrete gevolg zou zijn van het niet voldoen aan de verplichting.

De eerste reactie van zowel P. als S., voordat ieder van hen contact met me opnam, was paniek. Voor zover ieder van hen wist, betekende deze kennisgeving dat haar respectievelijke verblijfsvergunning als langdurig ingezetene ingetrokken zou worden en zij het land zou kunnen worden uitgezet, bij het niet behalen van het inburgeringsexamen binnen de gestelde termijn. Ik legde allereerst uit dat daar geen sprake van kon zijn. Uit in ieder geval artikel 12 van de Richtlijn vloeide voort dat zij alleen uitgezet kon worden indien zij een 'voldoende ernstige bedreiging voor de openbare orde of de openbare veiligheid' vormde. Ik legde uit dat de ergste sanctie een boete zou zijn.

Desondanks vonden P. en S. dat het oneerlijk en onrechtmatig was om zelfs met een boete te dreigen. In eerste instantie oneerlijk, omdat er geen inburgeringsvoorwaarde werd gesteld op grond van artikel 5 tweede lid Richtlijn voor het verlenen van de status, ${ }^{38}$ waardoor op grond van een redelijke a contrario-lezing, zo'n voorwaarde niet effectief achteraf mocht worden gesteld. Maar in tweede instantie vonden zij het onrechtmatig omdat een van de 'wortels' die de status van langdurig ingezetene voorstelde, als middel om hun integratie in Nederland te bevorderen, juist een recht op gelijke behandeling met Nederlanders was, in ieder geval op alle gebieden die in artikel 11 Richtlijn werden genoemd (waaronder toegang tot werk en onderwijs). Als de wetgever Nederlanders niet kon verplichten het inburgeringsexamen te behalen, ${ }^{39}$ waarom dan wel een langdurig ingezetene? Wél liet de Richtlijn toe dat een langdurig ingezetene die die status van langdurig ingezetene in een andere lidstaat had verworven, en gebruikmaakte van zijn rech-

37 Aanvankelijk is Richtlijn 2003/109 geïmplementeerd door de Nederlandse wetgever in de vorm van de voorwaarden voor het verlenen van een 'verblijfsvergunning regulier voor onbepaalde tijd' als zodanig, maar met wetswijzigingen sindsdien is dat conceptuele verband weer losgelaten. Een verblijfsvergunning als 'langdurig ingezetene' heet tegenwoordig gewoon letterlijk zo in de vreemdelingenwetgeving, en de verblijfsvergunning regulier voor onbepaalde tijd, die verleend wordt op grond van het nationaal recht en niet op grond van de Richtlijn, leidt een parallel bestaan.

38 Dus hier schuurde het dat het verband tussen de 'wortel' en de 'stok', een van de centrale politieke grondslagen van de Wi, ontbrak. 
ten van mobiliteit op grond van de Richtlijn, verplicht kon worden (op grond van artikel 15 derde lid) te voldoen aan integratievoorwaarden indien die persoon niet al in de eerste lidstaat aan integratievoorwaarden hoefde te voldoen op grond van artikel 5 tweede lid; nog een argument dat de a contrario-lezing van artikel 5 ondersteunde.

Verder plaatsten P. en S. vraagtekens bij de toelaatbaarheid van een boete in verband met ieders persoonlijke situatie en verleden met betrekking tot inburgeringsverplichtingen. S. zag niet meer in wat de meerwaarde was van de status van langdurig ingezetene: zij had die status met name aangevraagd om een hypotheek af te kunnen sluiten bij het kopen van een huis, maar dat zou haar waarschijnlijk ook gelukt zijn met haar vorige (voorwaardelijke) verblijfsdoel, 'verblijf als kennismigrant', waarmee zij 'tijdelijk' verblijf had en dus niet inburgeringsplichtig was. P., op haar beurt, hád al netjes voldaan aan de verplichting die aan haar op grond van de Win werd gesteld als gezinsmigrant: deelname aan een inburgeringsprogramma (op toen al 42-jarige leeftijd) voor in totaal 305 uren, afgesloten met een diploma dat aan haar uitgereikt werd namens het college van $B \& W$ van de gemeente Breda in 2004. Inmiddels had zij een baan als schoonmaakster en sprak ze prima Nederlands met haar collega's, maar het idee al dat zij hoe dan ook óf de kosten van het inburgeringsexamen (en de voorbereiding daarvoor) zou moeten betalen, óf een boete zou moeten betalen, dreef haar tot wanhoop. Voor haar voelde het alsof zij daadwerkelijk weggepest werd uit Nederland, zo'n beetje het enige land ter wereld, ten tijde van haar vestiging in Nederland in 2002, waar zij een gezinsleven kon opbouwen met haar Nederlandse vrouw. Zowel P. als S. voelden zich bovendien beknot in hun vrijheid om te werken, nu ieder van hen mogelijk minder uren zou moeten gaan werken om zich voor te bereiden voor het examen.

Toen beide zaken uiteindelijk in hoger beroep behandeld werden door de Centrale Raad van Beroep zag deze zich genoopt prejudiciële vragen te stellen ${ }^{40}$ aan het Hof van Justitie van de Europese Unie:

'1 Moet het doel en de strekking van Richtlijn 2003/109/EG, dan wel artikel 5, tweede lid en/of artikel 11, eerste lid, daarvan, aldus worden uitgelegd dat het op grond van nationale regelgeving opleggen van de inburgeringsplicht, gesanctioneerd door een boetestelsel, aan onderdanen van derde landen, die in het bezit zijn van de status van langdurig ingezetene, hiermee niet verenigbaar is?

2 Is het bij de beantwoording van de eerste vraag van belang of de inburgeringsplicht is opgelegd voordat de langdurig ingezetene-status werd verkregen?'

Het Hof oordeelde allereerst dat '[v]oor zover artikel 5, lid 2, van richtlijn 2003/109 de lidstaten gebiedt noch verbiedt om van derdelanders te vereisen dat zij na de verkrijging van de status van langdurig ingezetene integratievoorwaarden vervullen, verzet deze bepaling zich dus niet tegen een integratiemaatregel als aan de orde in het hoofdgeding. ${ }^{41}$ 
Voorts, met betrekking tot het beroep op de gelijke behandelingsbepalingen van artikel 11: 'In deze context moet worden vastgesteld dat de litigieuze integratiemaatregelen in wezen bestaan in de verplichting om mondelinge en schriftelijke vaardigheden in de Nederlandse taal en kennis van de Nederlandse samenleving te verwerven en/of aan te tonen. Terwijl kan worden aangenomen dat eigen onderdanen over dergelijke vaardigheden en kennis beschikken, geldt dat niet voor derdelanders. Zoals de advocaat-generaal in punt 52 van zijn conclusie heeft opgemerkt, moet bijgevolg worden vastgesteld dat, wat het nut betreft van integratiemaatregelen zoals de verwerving van kennis van de taal en de samenleving van het land, de situatie van derdelanders niet vergelijkbaar is met die van eigen onderdanen. ${ }^{42}$

Maar: 'Evenwel mag ook de wijze waarop uitvoering wordt gegeven aan deze verplichting, die doelen niet in gevaar brengen, met name rekening gehouden met het kennisniveau dat vereist is om het inburgeringsexamen te kunnen behalen, met de toegankelijkheid tot de cursus en tot het ter voorbereiding op dat examen benodigde materiaal, met de hoogte van de door derdelanders voor dat examen verschuldigde inschrijvingskosten of met bijzondere individuele omstandigheden, zoals leeftijd, analfabetisme of opleidingsniveau. ${ }^{\text {'3 }}$

Het Hof liet zich vervolgens kritisch uit over de verschillende wijzen waarop het Nederlandse inburgeringsstelsel al bijna in absolute termen, dus zonder rekening te hoeven houden met persoonlijke omstandigheden, de doelen van de Richtlijn in gevaar kan brengen, met de hoge maximale boete (toen nog 'slechts' $€ 1000$ ), het feit dat de boete herhaaldelijk kan worden opgelegd, zonder begrenzing, iedere keer dat de termijn opnieuw wordt overschreden, het feit dat de boete wordt opgelegd ongeacht of er een poging is gedaan om het examen te behalen en, tot slot, dat de inburgeringsplichtige zelf de kosten voor deelname aan het examen moet betalen ${ }^{44}$ en eventueel nog de kosten voor voorbereiding daarvoor moet dragen.

De eerste en tweede aangehaalde overwegingen kwamen zeker aan als een teleurstelling: het Hof vertikte het de rechtmatigheid (in een traditioneel-juridische zin) te toetsen van het opleggen van een boete aan een langdurig ingezetene - met andere woorden, het Hof liet na de status van langdurig ingezetene als een absoluut 'schild' van gelijke behandeling op te werpen, vergelijkbaar met het Unieburgerschap, waarmee de houder alle discriminatoire straffen kon afweren. Het Hof oordeelde als het ware: 'verschil moet er zijn tussen derdelanders en Unieburgers'. Vervolgens leek het alsof het Hof boetes in het Nederlandse inburgeringstelsel aan een haast politieke doelmatigheids-toets onderwierp.

Maar vergeleken met de zojuist geschetste bepalingen van het Nederlandse inburgeringsrecht blinkt het integratiebegrip, dat hier geschetst wordt door het Hof,

44 P. \& S., supra n. 21, par. 53. Tijdens de mondelinge behandeling, toen de kamerpresident de agent van Nederland vroeg of gezien de dreiging met een boete, het inburgeringsexamen tenminste gratis was, reageerde de kamerpresident met een niet te miskennen blik van verontwaardiging op het ontkennende antwoord van de agent. 
uit in rechtszekerheid en reële rechtvaardigheid. Allereerst: het hoeft geenszins vanzelfsprekend te zijn, zoals in de conceptie van de Nederlandse wetgever, dat het verplichten van een inburgeringsexamen per se moet worden opgevat als een 'stok' en/of als een 'wortel', op zo'n wijze dat het niet eerst stellen van een voorwaarde voor verkrijging van de status het alsnog opleggen van een boete uitsluit. Om te beginnen: de status van langdurig ingezetene, in de doctrine van het Unierecht, is geen 'bekroning' of eindpunt van het integratietraject van een derdelander. De status is geen beloning voor geslaagde integratie, wat dat dan ook mag betekenen. De status is juist bedoeld om de integratie van een derdelander verder te bevorderen, onder meer met bescherming tegen uitzetting en het gebod tot gelijke behandeling op de genoemde gebieden. Met deze rechten zal de derdelander in staat worden gesteld zich verder te ontwikkelen en ontplooien in de samenleving van de lidstaat waar hij of zij woont.

Een lidstaat kan dus ook integratiemaatregelen stellen om de verdere integratie van een langdurig ingezeten derdelander te bevorderen. Een boetestelsel kan erbij horen. Maar onder géén omstandigheden, aldus het Hof, mag dit meer als een straf worden ervaren dan als een prikkel. De termen 'evenredigheid' of 'proportionaliteit' treft men niet letterlijk aan in het arrest, maar de overwegingen van het Hof zijn kennelijk doordrenkt van het Unierechtelijke evenredigheidsbegrip.

In plaats van te focussen op allerlei formele kwaliteiten en voorwaarden waaraan een inburgeringsplichtige voldoet voor het al dan niet opleggen van een boete, zoals het stelsel van de Wet inburgering, toetst het Hof de toelaatbaarheid van een boete aan één simpele vraag: brengt de boete de nagestreefde doelen van de Richtlijn in gevaar? Met andere woorden: bevórdert een boete de integratie van een specifieke derdelander in de samenleving van de lidstaat waar hij woont, of bewerkstelligt de boete juist het tegenovergestelde?

(Voor de epiloog voor P. en S., trouwens, kan ik verwijzen naar de uitspraken op hun respectievelijke hoger beroepen door de verwijzende rechter: niet-ontvankelijk voor S., ${ }^{45}$ omdat zij inmiddels Unieburger was geworden, en een bestuurlijke lus t.a.v. P., ${ }^{46}$ aan de hand waarvan de gemeente Breda haar bezwaarschrift gegrond verklaarde.)

\section{Conclusie: óf positieve bevordering van inburgering voor iedereen, óf laat duizend rechtszaken bloeien}

Het zal niet verbazingwekkend zijn dat de wetgever nog steeds geen aanleiding heeft gezien, naar aanleiding van $P$. en $S$., om de Wi aan te passen. Allereerst omdat de formeel betroffen personen, namelijk houders van een verblijfsvergunning langdurig ingezetene die nooit een inburgeringsexamen hadden behaald (zonder vrijgesteld te hoeven worden), een geheel gesloten verzameling betreft 
die immer kleiner wordt. ${ }^{47}$ Iedereen die sinds 1-1-2010 een verblijfsvergunning als langdurig ingezetene heeft aangevraagd heeft het examen behaald of is vrijgesteld en kan om die reden ook nooit beboet worden.

Hoe dan ook: het ligt besloten in de overwegingen van het Hof dat een daadwerkelijke aanpassing van de Wet inburgering aan $P$. en $S$., terwijl er nog steeds wordt vastgehouden aan het beginsel van strenge boetes als een prikkel voor derdelanders om in te burgeren, een praktische nachtmerrie zou zijn om uit te voeren. De geobjectiveerde regels van de Wi, waarmee alle aspecten van het leven van een inburgeringsplichtige tot een complex van abstracties worden gereduceerd, maken het juist relatief makkelijk om boetes op te leggen zonder al te veel mensuren eraan te besteden. Maar een gedegen onderzoek naar de persoonlijke omstandigheden van iedere enkele inburgeringsplichtige bij het opleggen van een boete vergt juist heel veel ambtenarenwerk.

Bovendien lijkt het juist alsof the cruelty is the point van de wetgever, voor zover inburgeringsplichtigen worden geconfronteerd met rechtsonzekerheid. ${ }^{48}$ Straf en de onzekerheid, of die wordt opgelegd of niet, is juist bedoeld om de regel te zijn van het inburgeringsstelsel, voor de categorieën vreemdelingen die als vreemde lichamen in de Nederlandse samenleving worden beschouwd.

Zo worden hele groepen mensen al bij voorbaat gecriminaliseerd. Het woord 'inburgering' heeft al in de Nederlandse volksmond meer associaties met dwang dan met hulp, zozeer dat men schrikt wanneer men overweegt categorieën vreemdelingen, waarin men zijn eigen mensbeeld erkent, te onderwerpen aan inburgeringsvoorwaarden en -verplichtingen. Kenmerkend voor deze opvatting is een recente uitspraak van Tweede Kamerlid Jan Paternotte (D66) in een debat, ${ }^{49}$ waarin hij minister Koolmees oproept, in het belang van het bedrijfsleven, geen inburgeringsplicht aan Britten op de leggen na een eventuele no-deal-Brexit. Minister Koolmees, in zijn reactie, probeert Paternottes zorgen te ontzenuwen door uit te leggen dat de inburgeringsplicht sowieso niet zal gelden voor Britten die al gevestigd zijn in Nederland op het moment van een Brexit (omdat zij alsnog als Unieburgers zullen worden behandeld) en dat Britten-als-derdelanders die erna als arbeidsmigrant komen ook nooit (als zodanig) verplicht zullen worden om in te burgeren.

47 De ABRvS was van oordeel, in zeker een van de laatste gevallen van zo'n oud geval, dat het opleggen van een boete à $€ 250$ aan een langdurig ingezetene geen strijd opleverde met Richtlijn 2003/109 in het licht van $P$. en $S$. omdat geen bijzonderheden zich voordeden, ondanks de feiten dat zij voor kinderen moest zorgen en dat haar taalschool failliet ging, te meer omdat de boete voor $€ 15$ per maand kon worden afgelost. ABRvS 27 september 2017, ECLI:NL:RVS:2017:2603.

48 'Wie een ander onderwerpt aan een norm die niet van tevoren kenbaar is, behandelt die ander louter als middel ter bereiking van de eigen doeleinden.' Brouwer, 'Onvermijdelijke rechtsonzekerheid?', 186.

49 Handelingen Tweede Kamer, 6 maart 2019, nr. 59, item 8. De Telegraaf legde Paternotte in de mond een zelfs meer onverholen negativiteit over inburgering dan hoe hij zelf uitdrukte (cursivering toegevoegd): 'Wanneer er geen afspraken met Groot-Brittannië komen over een Brexit, moeten Britten die voor hun werk naar Nederland verhuizen niet meteen onder het juk van de inburgeringswetten komen te vallen. Dat vindt D66 uit vrees dat de taallessen Britse bedrijven ervan kunnen weerhouden om zich na de Brexit in Nederland te vestigen.' 'D66: geef Britten uitstel op inburgering bij harde Brexit.' 
Het wetsvoorstel ${ }^{50}$ van minister Koolmees voor een herziene Wi beoogt enigszins humaner te zijn, en meer maatwerk te bieden, maar houdt nog steeds vast aan het beginsel van een boetestelsel en een verwijtbaarheidsbegrip dat nog gebaseerd is op formalisme. Sterker nog, de inburgeringsplichtige wordt straks niet alleen geconfronteerd met boetes van DUO, maar ook van de gemeente, en wordt dus niet alleen geconfronteerd met rechtsonzekerheid in de vorm van complexe regels, maar ook in de vorm van diffuse handhavende instanties.

Het énige inburgeringsstelsel dat door de beugel kan voor het Hof, zonder de noodzaak voor al te veel casuïstiek, is er een dat bestaat bijna uitsluitend uit positieve bevordering van verwerving van de taal en culturele kennis van een lidstaat, en zo min mogelijk uit straffen en negatieve prikkels. ${ }^{51}$ Zoals advocaat-generaal Szpunar in zijn Conclusie stelde: 'De enige ontegenzeglijk toelaatbare vorm van financiële druk in bovengenoemde situatie is het bevel tot terugbetaling van de kosten die zijn gemaakt wegens de organisatie van de integratiehandelingen, wanneer de betrokken persoon zonder opgave van reden heeft afgezien van deelname aan integratiehandelingen. 52 Waarom moet de toegang tot cursussen, en leningen en giften ervoor (met een mogelijke kwijtschelding voor voldoende deelname als enige financiële prikkel), worden beperkt tot enkel inburgeringsplichtigen? ${ }^{53}$ Waarom wordt inburgering niet ook bevorderd voor 'expats', Unieburgers en zelfs volwassen Nederlanders die de taal op een laag niveau beheersen? Zolang er meer wordt gefocust op boetes dan op bevordering, zullen boetes nog moeten worden aangevochten voor de rechter.

Ondanks het feit dat er zo goed als geen betroffen langdurig ingezetenen (meer) zijn, zal het arrest $P$. en $S$. zonder twijfel een tweede leven leiden in de analoge toepassing van daarin opgevatte overwegingen op begunstigden van andere derdelander-Richtlijnen, ook al heeft het Hof nog niets bepaald over de toelaatbaarheid van boetes voor die derdelanders (m.n. gezinsmigranten en asielmigranten).

50 www.internetconsultatie.nl/veranderopgave_inburgering.

51 Zie ook, in het algemeen, het wetsadvies aan Koolmees door de ACVZ dat grotendeels dezelfde conclusies trekt: Adviescommissie voor Vreemdelingenzaken, 'Wetsadvies "Voorstel van wet houdende regels over inburgering in de Nederlandse samenleving” (Wet inburgering 20..)'.

52 Conclusie in P. \& S., 28 januari 2015, par. 103. In tegenstelling tot het Hof gaat de A-G uitdrukkelijk in op de problematiek van boetes als 'straf' en overweegt hij uitdrukkelijk of zo'n straf evenredig is.

53 Een begunstigde van Richtlijn 2004/81 (betreffende de verblijfstitel die in ruil voor samenwerking met de bevoegde autoriteiten wordt afgegeven aan onderdanen van derde landen die het slachtoffer zijn van mensenhandel of hulp hebben gekregen bij illegale immigratie), die op grond van de Wi een 'tijdelijke' verblijfsstatus heeft, en dus niet inburgeringsplichtig is, heeft tevergeefs een poging gedaan om een lening aan te vragen voor inburgeringsvoorzieningen. Haar eerste hoger beroep bij de ABRvS is gegrond verklaard (11 januari 2017, ECLI:NL:RVS:2017:35) omdat de rechtbank onvoldoende had onderzocht of het niet-toekennen van een lening in strijd was met de Richtlijn. Helaas faalde haar tweede hoger beroep (20 februari 2019, ECLI:NL:RVS: 2019:512) op de curieuze overweging van de Afdeling dat de Richtlijn alleen een verplichting schept om toegang te verschaffen tot gratis onderwijsprogramma's die door de overheid zelf worden geboden, maar niet om een lening toe te kennen voor inburgeringscursussen tegen betaling. 
Kort op de hielen van $P$. en $S$. volgde $K$. en $A .,{ }^{54}$ over de toelaatbaarheid van het stellen van een voorwaarde van een basisexamen inburgering voor begunstigden van de Gezinsherenigingsrichtlijn (Richtlijn 2003/86). Dit ging niet over boetes, maar het Hof verwees naar P. en S. en herhaalde de kernoverweging: 'Voorts moeten bijzondere individuele omstandigheden, zoals leeftijd, opleidingsniveau, financiële situatie of gezondheidstoestand van de betrokken gezinsleden van de gezinshereniger, in aanmerking worden genomen, teneinde hen vrij te stellen van de verplichting om het examen als aan de orde in de hoofdgedingen met goed gevolg af te leggen wanneer blijkt dat zij, vanwege die omstandigheden, niet in staat zijn dat examen af te leggen of daarvoor te slagen.' 55

Enige tijd later volgde $C$. en $A$., eveneens over begunstigden van de Gezinsherenigingsrichtlijn, en dit keer over de toelaatbaarheid van een inburgeringsvoorwaarde voor het verwerven van een autonome verblijfsstatus na vijf jaar verblijf als gezinsmigrant, met een uitdrukkelijke verwijzing naar $K$. en $A$. en overwegingen 'dat de bijzondere individuele omstandigheden naar behoren in aanmerking worden genomen en dat de kosten voor dat examen niet buitensporig zijn'.

Ik heb dus geen twijfel dat het leerstuk van $P$. en $S$. zonder meer van toepassing is op boetes voor late inburgering die worden opgelegd aan derdelanders die begunstigden zijn van de Gezinsherenigingsrichtlijn. En wat dat betreft heb ik geen twijfel dat de aller-kwetsbaarste derdelanders, begunstigden van de Kwalificatierichtlijn (Richtlijn 2011/95), recht hebben op een persoonlijke beoordeling van de evenredigheid van een opgelegde boete, én van de evenredigheid van een terugbetalingsplicht. Dat vloeit zelfs bijna vanzelfsprekend voort uit artikel 34 van die Richtlijn. ${ }^{56}$

Het pragmatisme van het Unierecht, waarmee een begunstigde precies weet waar hij aan toe is, namelijk gehólpen worden, dient de rechtszekerheid veel beter dan het complexe, ondoorzichtige boetestelsel van de Wet inburgering.

\section{Bibliografie}

Adviescommissie voor Vreemdelingenzaken, 'Wetsadvies "Voorstel van wet houdende regels over inburgering in de Nederlandse samenleving" (Wet inburgering 20..)', september 2019. https://acvz.org/pubs/stimuleer-alle-nieuwkomers-omin-te-burgeren/. 2015:453.

55 K.\& A., supra n. 69, par. 58.

56 'Toegang tot integratievoorzieningen. Teneinde de integratie van personen die internationale bescherming genieten in de samenleving te vergemakkelijken, bieden de lidstaten toegang tot integratieprogramma's welke zij passend achten om rekening te houden met de specifieke behoeften van personen met de vluchtelingenstatus of de subsidiairebeschermingsstatus, of zorgen zij voor de omstandigheden waaronder de toegang tot dergelijke programma's gewaarborgd is.' 
Brouwer, P.W. 'Basic concepts of European private law'. In: Coherentie, rechtszekerheid en rechtspositivisme: verspreide opstellen van prof. mr. P.W. Brouwer (1952-2006), 269-94. Den Haag: Boom Juridische uitgevers 2008.

Brouwer, P.W. 'Onvermijdelijke rechtsonzekerheid?' In: Coherentie, rechtszekerheid en rechtspositivisme: verspreide opstellen van prof. mr. P.W. Brouwer (1952-2006), 177-204. Den Haag: Boom Juridische uitgevers 2008.

'D66: geef Britten uitstel op inburgering bij harde Brexit'. De Telegraaf, 20 februari 2019, sec. Binnenland. www.telegraaf.nl/nieuws/3182488/d66-geefbritten-uitstel-op-inburgering-bij-harde-brexit.

Groenendijk, Kees. 'Legal Concepts of Integration in EU Migration Law'. European Journal of Migration and Law 6, nr. 2 (2004): 111-26. https://doi.org/ 10.1163/1571816042885969.

'Inburgering: systeemwereld versus leefwereld; Evaluatie Wet inburgering 2013'. Barneveld: Significant, 13 juni 2018.

Odé, A. en M. Brink. 'Verscheidenheid in integratie. Evaluatie van de Wet inburgering nieuwkomers'. Migrantenrecht 2002, nr. 5 (z.d.): 154-71.

Oers, Ricky van. Deserving Citizenship. Brill | Nijhoff 2014. https://doi.org/ 10.1163/9789004251076.

Spijkerboer, Thomas. Zeker weten: inburgering en de fundamenten van het Nederlandse politieke bestel. Den Haag: Sdu 2007.

Wet van 9 april 1998, houdende regels met betrekking tot de inburgering van nieuwkomers in de Nederlandse samenleving, Pub. L. No. Staatsblad 1998, 261 (1998).

Wet van 30 november 2006, houdende regels inzake inburgering in de Nederlandse samenleving, Pub. L. No. Staatsblad 2006, 625 (2006).

Woude, Maartje A.H. van der, Joanne P. van der Leun en Jo-Anne A. Nijland. 'Crimmigration in the Netherlands'. Law \& Social Inquiry 39, nr. 03 (2014): 560-79. https://doi.org/10.1111/lsi.12078.

Woude, Maartje van der. 'Crimmigratie: What's in a word?'. Crimmigratie \& Recht 2, nr. 1 (april 2018): 3-6. https://doi.org/10.5553/CenR/25429248201800200 1001. 